Kinestetik : Jurnal Ilmiah Pendidikan Jasmani 5 (4) (2021)

Kinestetik : Jurnal Ilmiah Pendidikan Jasmani

https://ejournal.unib.ac.id/index.php/kinestetik/index

DOI : 10.33369/jk.v5i4.18240

\title{
THE APPLICATION OF SKIMMING AND SCANNING TECHNIQUE TO STRENGTHEN THE UNDERSTANDING OF SPORTS MANAGEMENT MATERIAL OF PHYSICAL EDUCATION STUDENTS
}

\author{
Muhammad Imam Rahmatullah ${ }^{1 *}$, Dinan Mitsalina ${ }^{2}$, Endang Murti \\ Sulistyowati $^{3}$, Sri Ayu Wahyuti ${ }^{4}$, Elsya Desviyanti ${ }^{5}$ \\ ${ }^{15}$ Physical Education, Health And Recreation, Faculty Of Teacher Training And Education, \\ Universitas Riau, Indonesia \\ ${ }^{2}$ Faculty Of Sports Science, Universitas Negeri Jakarta, Indonesia \\ ${ }^{34}$ Sport Coaching, Universitas Negeri Yogyakarta, Indonesia
}

Article Info

Article History :

Received : Oktober 2021

Revised : November 2021

Accepted : December 2021

Available online : December 2021

Keywords:

Skimming, Scanning, Reading, Sports Management

\begin{abstract}
This study aims to improve the technical ability of students in reading references related to learning process. The basis of this research is based on case studies and role play. The technique used in this research is skimming and scanning techniques. The course taken in this study is subject that researchers are capable of in learning process, namely sports management. Based on the process, this research is categorized using quantitative and qualitative approaches to strengthen research data. The subject used in this study is 30 students of the Physical Education Health and Recreation Study Program, Faculty of Teacher Training and Education, the University of Riau. In accumulating the data, the researchers took all the data by means of observation and questionnaire. The quantitative data obtained in this study were analyzed by using software with the results in the form of percentages, maximum scores, and averages. While the qualitative data in this study were analyzed by making a narration, describing the data that were taken and then concluding the final results of the study. It can be concluded that there is a significant difference in student's satisfaction before and after the treatment of skimming and scanning techniques in sport management course. The satisfaction obtained from the skimming and scanning techniques can trigger selfmotivation from students to continue reading from various references and can affect the emergence of student's interest in writing.
\end{abstract}

Corresponding address : Kampus Bina Widya KM. 12,5, Simpang

ISSN 2685-6514 (Online)

Baru, Kec. Tampan, Kota Pekanbaru, Riau 28293

ISSN 2477-331X (Print)

*Email : muhammadimamrahmatullah@lecturer.unri.ac.id 


\section{INTRODUCTION}

Reading culture is an important ability that must be possessed by an individual. Students as academics are required to have reading culture. Reading is one way to invest student's free time (Katan \& Andreas Baarts, 2020). Reading is one way to improve the creative process and train critical thinking (Jose \& Dharma Raja, 2011). One of the ways to practice reading skills, in this case, is to read references in each course that is followed. Students often read scientific research papers to gain knowledge efficiently (Fukuhara \& Kojiri, 2019). References that students have in broadening their academic insight can be obtained from various sources. Not only for adding academic insight, but also reading skills according to Aryadoust \& Zhang (2016) can also integrate student's knowledge. Reference sources that can be obtained or accessed by students usually consist of scientific journals, books, previous research such as theses and dissertations.

The current learning tradition in reading scientific journals and other references emphasizes reading in full. Reading in full is certainly beneficial if there is much time. In fulfilling tasks such as paper, writing articles and proposals, students are constrained in time because they have to read the journal entirely, while the time given is limited. In addition, reading skills are useful for sorting information from all access sources. This information sorting process can be conceptualized with two concepts, namely, search criteria and search evaluation (Braasch et al., 2009).

Freedom to learn, which the flagship program is promoted by the Minister of Education of the Republic of Indonesia, gives us direction to continue to upgrade and innovate in developing knowledge. The task of developing this knowledge is surely the task of lecturers in carrying out the Tri Dharma in college. The techniques used by researchers for helping students in reading are skimming and scanning techniques. Skimming technique is a reading technique in a faster way to determine the main idea in a reading text (Laguado, 2013; Maxwell, 1972) (Darmawan, 2017; Marliasari, 2017; Tina Mariany Arifin, 2012). While scanning technique is a technique of looking for something or scanning information at a glance (Harmer, 2007; (I. R et al., 2018; Marliasari, 2017; Yanti Mambua, 2020)). Scamming and scanning techniques are good in practicing reading comprehension skills. In the context of this study, the researchers argued that the whole reading technique alone is not appropriate to provide convenience in understanding reading text. Another perspective is needed in improving student's reading comprehension. This reading comprehension is used to strengthen the understanding of sports management course.

Basically, sports management consists of combination of management and sports knowledge. The definition of management is a way used to utilize one's energy and thought in an integrated activity to achieve predetermined goals (Multi Media-Based Education Management, Sulfemi, Wahyu Bagja. 2019). In order to meet the objective, there are some techniques that can be done which are planning, organizing, directing, controlling, budgeting, leading and evaluating (Yoghik Ardianto, 2019). While the definition of sport according to Ayu (2015) is a necessity in life that is periodic. It means that sport is an instrument in maintaining and improving one's health. In 
addition, sport is also a cause of physical, spiritual and social growth and development.

Management in sport is the process of coordination with main resource and successful collaboration with stakeholders to facilitate the realization of the effective goal of business and sport from organizations and athletes in all management processes. Besides the classic elements of the definition of management, namely the process and main organization functions such as planning, execution and monitoring, it also classifies the definition the concept of main resource, which can differ significantly among sport organizations, depending on factors such as the type of sport organization, its size, mission and decision-making process (Retar \& Bednarik, 2018). Sports management is an integration of knowledge related to planning, organizing, directing, controlling, budgeting, leading, and evaluating in the position of the organization that makes sport as the main point. Sports management is an educational concept of a university prepared for students with an interest in taking part in the sports industry. Sports management itself refers to all people, forms of activity, business and the existence of an organization that is involved in managing activities and designing, providing, offering, and organizing every sport-related activity. It should be noted that there are four specific aspects of sports management including sports marketing, financial governance of sports industry, sports profession and social institutions (Cooper et al., 2016; Kogiso et al., 2015; Russell Hoye et al., n.d.).

Lecturers as subjects who transfer knowledge can see from a broader side in developing knowledge. This broader side is surely obtained if a lecturer is able to think elaborately. This improvement in reading with skimming and scanning techniques can be supported by the presence of technology in education. Students can use various software to support each stage in learning process. However, in learning process using technology, the assignments given by students need to be kept in mind to avoid plagiarism. One way to prevent that is by using Turnitin software. The researchers hope that the students of the Physical Education Health and Recreation Study Program, Faculty of Teacher Training and Education, the University of Riau are able to take main ideas from each source or reading reference accurately and with precision in working on paper assignments or in writing thesis and also followed by scientific principles in maintaining the quality of a reading.

\section{METHODS}

The research method used in the application of skimming and scanning techniques to strengthen the understanding of sports management material of physical education students is mixed method (Mixed Method Research). Mixed Method is a method in which researchers collect and analyze data, integrate findings, and draw conclusions using both qualitative and quantitative approaches or methods in one study or investigation program (LindsaySmith et al., 2018; Molina-Azorin, 2016; Regnault et al. ., 2018; Timans et al., 2019). Mixed method combines qualitative and quantitative approaches with a specific design to answer the research objectives (Creswell, 2012). The research design used is The Explanatory Sequential Design where in this design, there are 2 interactive sequential phases which can be seen in Figure 1. The first stage is taking and analyzing quantitative data which have priority to answer research questions. The next stage, the qualitative data collection 
phase is carried out following the previous phase (Cohen et al., 2017; Creswell, 2012). In sports management, qualitative research is often conducted as a case study or case research design, using semistructured interviews as the primary means of data collection and some form of coding as an approach to data analysis (Shaw \& Hoeber, 2016). Interview is a valuable tool because resource person can explore treatments and thus provide opportunities for discussion and confirmation (Stride et al., 2016).

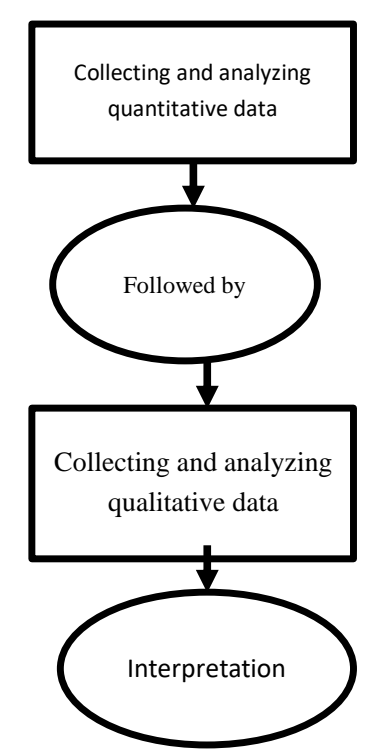

Figure 1. The Explanatory Sequential Design (Creswell, 2012)

The sample of this research was the fifth semester students who are taking sports management course at the University of Riau, Physical Education Health and Recreation Study Program,. There were 30 students. The sampling process used purposive sampling technique which is in accordance with the number of students who are taking sports management course in the fifth semester of 2020-2021 Academic Year.

The process of collecting data both quantitative and qualitative data is carried out simultaneously, namely observation and filling out a questionnaire. Qualitative data were obtained from direct observation by lecturers to students. While Quantitative data were obtained from the result of questionnaires that had been given to the students. The instrument used in the data collection was a questionnaire of 8 questions. Quantitative data obtained in this study were analyzed by software with the results in the form of percentages, scores, and averages. The calculation of the percentage formula is as follows:

$$
P S=\frac{S T}{S M} \times 100 \%
$$

Description:

PS $=$ Score Percentage

$\mathrm{ST}=$ total score generated

$\mathrm{SM}=$ Maximum score which should have been got (Sugiyono, 2015)

While the qualitative data in this study were analyzed by making a narrative and describing the data and then concluding the final result of the study.

\section{RESULTS}

Table 1. The result of students' satisfaction toward the use of skimming and scanning technique

\begin{tabular}{lllll}
\hline $\begin{array}{l}\text { Treatm } \\
\text { ent }\end{array}$ & $\begin{array}{l}\text { Avera } \\
\text { ge } \\
\text { score }\end{array}$ & $\begin{array}{l}\text { Categ } \\
\text { ory }\end{array}$ & $\begin{array}{l}\text { Freque } \\
\text { ncy }\end{array}$ & $\begin{array}{l}\text { Percent } \\
\text { age }\end{array}$ \\
\hline Before & 69.87 & High & 12 & $40 \%$ \\
& & Low & 18 & $60 \%$ \\
\hline After & 79,17 & High & 25 & $83,33 \%$ \\
& & Low & 5 & $16,67 \%$ \\
\hline
\end{tabular}

Table 2. Independent sample test

\begin{tabular}{|c|c|c|c|c|c|c|c|c|}
\hline $\mathbf{F}$ & $\begin{array}{l}\mathbf{S i} \\
\mathbf{g}\end{array}$ & $\mathbf{t}$ & df & $\begin{array}{l}\text { Si } \\
\text { g. } \\
\text { (2- } \\
\text { Ta } \\
\text { ile } \\
\text { d }\end{array}$ & $\begin{array}{l}\text { Mea } \\
\text { n } \\
\text { Diffe } \\
\text { renc } \\
\text { e }\end{array}$ & $\begin{array}{l}\text { Std. } \\
\text { Erro } \\
\text { r } \\
\text { Diffe } \\
\text { renc } \\
\text { e }\end{array}$ & $\begin{array}{l}\text { Lo } \\
\text { we } \\
\mathbf{r}\end{array}$ & $\begin{array}{l}\text { Up } \\
\text { pe } \\
\mathbf{r}\end{array}$ \\
\hline 8. & .0 & - & 58 & .02 & - & 4.09 & - & - \\
\hline 01 & 0 & 2. & & 7 & 9.30 & 8 & 17. & 1.0 \\
\hline \multirow[t]{5}{*}{6} & 6 & $\begin{array}{l}27 \\
0\end{array}$ & & & 0 & & $\begin{array}{l}50 \\
2\end{array}$ & 98 \\
\hline & & - & 44. & .02 & - & 4.09 & - & - \\
\hline & & 2. & 35 & 8 & 9.30 & 8 & 17. & 1.0 \\
\hline & & 27 & 8 & & 0 & & 55 & 44 \\
\hline & & 0 & & & & & 6 & \\
\hline
\end{tabular}




\section{DISCUSSION}

Learning techniques significantly affect student satisfaction in learning. The level of student satisfaction in lesson is an important component to acquire knowledge or skills as well as a significant predictor of learning outcomes (Eom et al., n.d.). A student can be considered satisfied if he feels that the course can meet his needs and expectations. This can motivate students to put more effort into learning activities. The analysis of the similarity test of the two averages was carried out with the help of the SPSS 22 application for Windows, namely the independent sample t-test. The result of the similarity of the two averages to the sample treatment can be seen in Table 2. The difference in the similarity of the two averages in the study can be seen from the significance value $<0.05$. Based on the result of the similarity test of two averages shown in table 2, it can be concluded that there are significant differences in student satisfaction before and after treatment. Previous research conducted by Indah, 2018 confirmed that skimming and scanning techniques were very effective in improving students' reading skills. This confirms the position of the researcher to strengthen the basis of this research.

\section{CONCLUSION}

It can be concluded that the treatment of skimming and scanning techniques in sport management course is effective because there are significant differences in student satisfaction before and after treatment. The effect of skimming reading techniques makes students know more quickly whether the text needs to be read further or not to be continued in the book and sport management articles. While the scanning technique is useful when students are looking for specific information in sport management books and articles. The satisfaction obtained from the skimming and scanning techniques can trigger self-motivation from students to continue reading from various references and can affect the emergence of student's interest in writing. Skimming and scanning reading techniques need to be carried out on an ongoing basis in all subjects, not only in sports management course, because they are very useful to support the achievement of scientific writing and thesis preparation.

\section{REFERENCES}

Aryadoust, V., \& Zhang, L. (2016). Fitting The Mixed Rasch Model To A Reading Comprehension Test: Exploring Individual Difference Profiles In L2 Reading. Language Testing, 33(4), 529-553. Https://Doi.Org/10.1177/0265532215 594640

Braasch, J., Lawless, K., Goldman, S., Manning, F., Gomez, K., \& Macleod, S. (2009). Evaluating Search Results: An Empirical Analysis Of Middle School Students' Use Of Source Attributes To Select Useful Sources. Journal of Educational Computing Research, 41(1), 63-82. Https://Doi.Org/10.2190/EC.41.1.C

Cohen, L., Manion, L., \& Morrison, K. (2017). Research Methods In Education. In Research Methods In Education.

Https://Doi.Org/10.4324/9781315456 539

Cooper, J. N., Grenier, R. S., \& Macaulay, C. (2016). Autoethnography As A Critical Approach In Sport Management: Current Applications And Directions For Future Research. Sport Management Review, 1-12. Https://Doi.Org/10.1016/J.Smr.2016. 07.003

Creswell, J. W. (2012). Educational Research: Planning, Conducting, And Evaluating Quantitative And Qualitative Research (4th Ed.). Pearson Education.

Darmawan, S. L. (2017). The Implementation Of Skimming Technique Towards Students' 
Reading Comprehension. PREMISE JOURNAL:ISSN Online: 2442-482x, ISSN Printed: 2089-3345, 5(2), 1. Https://Doi.Org/10.24127/Pj.V5i2.81 1

Eom, S. B., Wen, H. J., \& Ashill, N. (N.D.). The Determinants Of Students' Perceived Learning Outcomes And Satisfaction In BINUS Online Learning. Decision Sciences Journal Of Innovative Education, 4(2), 213235.

Https://Doi.Org/Https://Doi.Org/10.1 111/J.1540-4609.2006.00114.X

Fukuhara, K., \& Kojiri, T. (2019). Paper Introduction Presentation Support Environment For Reading Skill And Presentation Skill Development. Procedia Computer Science, 159, 2041-2050.

Https://Doi.Org/10.1016/J.Procs.2019 .09 .377

I. R, A., S, L., \& D, K. (2018). The Analysis Of Skimming And Scanning Technique To Improve Students In Teaching Reading Comprehension. PROJECT (Professional Journal Of English Education), 1(2), 101-106.

Jose, R., \& Dharma Raja, B. W. (2011). Teachers Role In Fostering Reading Skill: Effective And Successful Reading. I-Manager's Journal On English Language Teaching, 1(4), 110.

Https://Doi.Org/10.26634/Jelt.1.4.159 9

Katan, L., \& Andreas Baarts, C. (2020). Inquiry-Based Reading - Towards A Conception Of Reading As A Research Method. Arts And Humanities In Higher Education, 19(1), $58-75$. Https://Doi.Org/10.1177/1474022218 760261

Kogiso, K., Oshimi, D., \& Harada, M. (2015). Sports Management And Sports Humanities Kazuyuki Kanosue Editor In Chief.

Laguado, J. C. (2013). Improving Reading Skills Through Skimming And
Scanning Techniques At A Public School: Action Research. Opening Writing Doors Journal, 10(1), 133150.

Lindsay-Smith, G., O’Sullivan, G., Eime, R., Harvey, J., \& Van Uffelen, J. G. Z. (2018). A Mixed Methods Case Study Exploring The Impact Of Membership Of A Multi-Activity, Multicentre Community Group On Social Wellbeing Of Older Adults. BMC Geriatrics, 18(1), 1-14. Https://Doi.Org/10.1186/S12877-0180913-1

Marliasari, S. (2017). Teaching Reading Comprehension By Using Skimming And Scanning Techniques To The Tenth Grade Students Of Sman 1 Gelumbang. English Community Journal, $1(2), \quad 109$. Https://Doi.Org/10.32502/Ecj.V1i2.7 68

Maxwell, M. J. (1972). Skimming And Scanning Improvement: The Needs, Assumptions And Knowledge Base. Journal Of Literacy Research, 5(1), 47-59.

Https://Doi.Org/10.1080/1086296720 9547021

Molina-Azorin, J. F. (2016). Mixed Methods Research: An Opportunity To Improve Our Studies And Our Research Skills. European Journal of Management And Business Economics, 25(2), 37-38. Https://Doi.Org/10.1016/J.Redeen.20 16.05.001

Regnault, A., Willgoss, T., \& Barbic, S. (2018). Towards The Use Of Mixed Methods Inquiry As Best Practice In Health Outcomes Research. Journal Of Patient-Reported Outcomes, 2, 2 5. Https://Doi.Org/10.1186/S41687018-0043-8

Retar, I., \& Bednarik, J. (2018). The Definition Of Sports Management. Science And Research Centre, Institute For Kinesiology Research, Koper, University of Primorska, Slovenia, St. Titov, Vol. 13, N(July). 
Russell Hoye, A. C. T. S., Nicholson, M., \& Stewart, B. (N.D.). Sport Management.

Stride, A., Fitzgerald, H. F., \& Allison, W. (2016). A Narrative Approach: The Possibilities For Sport Management. Sport Management Review. Https://Doi.Org/10.1016/J.Smr.2016. 10.002

Sugiyono. (2015). Statistika Untuk Penelitian. Alfabeta.

Timans, R., Wouters, P., \& Heilbron, J. (2019). Mixed Methods Research: What It Is And What It Could Be. Theory And Society, 48(2), 193-216. Https://Doi.Org/10.1007/S11186-01909345-5

Tina Mariany Arifin, B. J. W. H. A. (2012). The Effect Of Applying Skimming Technique On Grade XI Students' Reading Comprehension. REGISTER Journal Of English Language Teaching Of FBS-Unimed, 1(1), 1-15. Https://Doi.Org/10.24114/Reg.V1i1.3 95

Yanti Mambua. (2020). The Effectiveness Of Skimming And Scanning Techniques In Improving Student's Reading Comprehension Of Grade Eleven Students Of SMA Negeri 1 Tana Toraja. Journal of Sosial Science, $\quad$ 1(3), 93-99. Https://Doi.Org/10.46799/Jsss.V1i3.3 8 